\title{
TNFRSF9 Gene
}

National Cancer Institute

\section{Source}

National Cancer Institute. TNFRSF9 Gene. NCI Thesaurus. Code C105111.

This gene plays a role in receptor signaling in T-cells. 